IZA DP No. 4297

Trust and Control at the Workplace:

Evidence from Representative Samples of

Employees in Europe

Christian Grund

Christine Harbring

July 2009 


\title{
Trust and Control at the Workplace: Evidence from Representative Samples of Employees in Europe
}

\author{
Christian Grund \\ University of Würzburg \\ and IZA \\ Christine Harbring \\ University of Cologne \\ and IZA
}

Discussion Paper No. 4297

July 2009

IZA

P.O. Box 7240

53072 Bonn

Germany

Phone: +49-228-3894-0

Fax: +49-228-3894-180

E-mail: iza@iza.org

\begin{abstract}
Any opinions expressed here are those of the author(s) and not those of IZA. Research published in this series may include views on policy, but the institute itself takes no institutional policy positions.

The Institute for the Study of Labor (IZA) in Bonn is a local and virtual international research center and a place of communication between science, politics and business. IZA is an independent nonprofit organization supported by Deutsche Post Foundation. The center is associated with the University of Bonn and offers a stimulating research environment through its international network, workshops and conferences, data service, project support, research visits and doctoral program. IZA engages in (i) original and internationally competitive research in all fields of labor economics, (ii) development of policy concepts, and (iii) dissemination of research results and concepts to the interested public.
\end{abstract}

IZA Discussion Papers often represent preliminary work and are circulated to encourage discussion. Citation of such a paper should account for its provisional character. A revised version may be available directly from the author. 


\title{
ABSTRACT
}

\section{Trust and Control at the Workplace: Evidence from Representative Samples of Employees in Europe}

\begin{abstract}
Based on two representative samples of employees, the German Socio Economic Panel and the European Social Survey, we explore the relation between certain measures of control in employment relationships (i.e. working time regulations, use of performance appraisal systems, monitoring by supervisors, autonomy to organize the work) and individuals' inclination to trust others. Trust is measured by the general trust question like in most other economic studies based on surveys. We find that strict working time regulations, monitoring and lack of autonomy - all indicators for control at the workplace - are negatively related to trust. Moreover, we contribute to the literature on trust by gathering hints to other potential determinants of trust.
\end{abstract}

JEL Classification: D03, J81, M12, M5

Keywords: autonomy, control, monitoring, performance appraisal, regulation of working time, trust

Corresponding author:

Christian Grund

University of Würzburg

Department of Business and Economics

Sanderring 2

97070 Würzburg

Germany

E-mail: ch.grund@uni-wuerzburg.de 


\section{Trust and Control at the Workplace \\ Evidence from Representative Samples of Employees in Europe}

\section{Introduction}

It has been acknowledged for years that trust - often associated with social capital - is an essential ingredient of economic transactions within and outside of organizations. Knack and Keefer (1996), for example, showed in their seminal paper that the growth of a nation's economy is positively associated with the degree of trust towards others. To understand the determinants of trust a variety of analyses have identified possible candidates for growing (or destroying) trust. For instance, education has been identified as a major determinant of trust indicating that trust is a moral attitude that can be acquired (e.g. La Porta et al. 1997, Bellemare/Kröger 2007). Moreover, the environment (see e.g. Rainer/Siedler forthcoming who analyze the impact of a political regime) or specific experiences of individuals (see e.g. Alesina/La Ferrara 2002) seem to influence trust attitudes.

We follow this literature assuming that trust as an attitude might be shaped by the attributes of an individual's environment. Based on this assumption we analyze the impact of workplace characteristics on an individual's trust level as the workplace is of major importance in most employees' lives. In particular, we focus on different variables approximating the degree of control at the workplace of employees. Our conjecture is that people who are frequently and intensely monitored at work tend to trust less as they learn that others expect them not to act trustworthily which might be interpreted as a general social norm. Dickinson/Villeval (2004) as well as Falk/Kosfeld (2006) provide some experimental support for a similar effect by showing that the principal's intensity of control may have a negative impact on the agents' work effort.

In economic analyses the degree of trust exhibited is usually approximated by either taking the general trust question from the World Values Survey and the General Social Survey (GSS), i.e. "Generally speaking, would you say that most people can be trusted or that you can't be too careful in dealing with people?”1 or a behavioral measure from experiments. The general trust question has been included in the wave of 2003 of the German Socio-Economic Panel (GSOEP) which is a representative dataset of the population in Germany. It is also

\footnotetext{
${ }^{1}$ According to Sapienza/Toldra/Zingales (2007) around 500 papers are based on the answers of this general trust question.
} 
included in the first three waves $(2002,2004,2006)$ of the European Social Survey (ESS) Moreover, different variables in the GSOEP and the ESS regarding control at the workplace can be used for our analysis as well as a variety of information on the individual employee as well as the employer.

In the following section the related literature is summarized. The section closes with a description of our underlying hypotheses. The German dataset with the variables, the methodology of our analysis as well as the results are explained in section 3. Analogously, we describe the European dataset and results of the analysis in the subsequent section 4. Finally, section 5 concludes.

\section{Related Literature}

Several studies have already focused on the determinants of trust attitudes. It is important to note here that in our study as well as in the large majority of the related analyses based on questionnaire data it is not possible to identify the causal direction of the effects unambiguously. The logic of the causal direction we assume here is completely in line with other studies: We conjecture that aspects of an individual's environment and individual experiences made may have an impact on the general trust attitude towards others. However, we are not able to empirically prove the causal direction of the effect as we lack panel data.

For example, Alesina/La Ferrara (2002) approach the question of who trusts others investigating different individual and social characteristics using information from the General Social Survey from 1974 - 1994. They find that low trust is rather associated with recent traumatic experiences, with belonging to a group that felt historically discriminated against, with being economically unsuccessful as well as living in a heterogeneous community regarding race and income.

In some recent studies the methodology of measuring trust is addressed. For example, Fehr et al. (2002) combine a representative survey including the standard trust questions from the General Social Survey with behavior in an experiment to investigate the relationship between attitudes elicited by survey questions and actual (incentivized) behavior. Like our study theirs is also based on the GSOEP. Besides identifying several correlates of trust they find that the trust attitudes elicited by the standard survey questions are mostly in line with behavior in the experiment. Bellemare/Kröger (2007) follow a similar approach by analyzing a representative Dutch data set, i.e. the CentERpanel. They also compare trust attitudes elicited by the 
standard trust survey questions with behavior in an investment game (see Berg/Dickhaut/McCabe 1995) integrated into the questionnaire. ${ }^{2}$ They may confirm a positive relationship between behavior in an investment game and the general trust question as well.

Moreover, Rainer/Siedler (forthcoming) show in an interesting study that the level of individuals' trust in a society is shaped by the political regime in which they live. They particularly focus on the difference between East and West Germany. Their study is based on ALLBUS which is the German equivalent of the General Social Survey as well as on some additional information from GSOEP. They compare trust attitudes of East and West Germans shortly after the reunification as well as more than a decade later and find that East Germans tend to trust less measuring trust by the general trust question.

The studies mentioned so far do not involve any variables related to corporate characteristics or activities. In an interesting study by La Porta et al. (1997) the authors focus on large companies' sales in relation to a country’s GNP and they may confirm the hypothesis of Fukuyama (1995) that large-scale activities should be facilitated by trust in a society.

However, all of these studies do not analyze the correlation of trust with processes or regulations within companies such as certain human resource practices or workplace regulations, e.g. working time. ${ }^{3}$ The question whether the internal mechanisms of companies may have an affect on trust is approached in a different strand of literature which methodologically differs from the above studies. One major difference to our study is, for example, that another concept of trust is analyzed. Usually, trust within the company, i.e. typically interpersonal trust of employees towards management, is analyzed and not the general trust level like in the studies mentioned above.

For instance, Mayer/Davies (1999) conduct a survey in a small company investigating the effect of a newly introduced performance appraisal system on workplace trust. By investigating data from this quasi-experiment conducted in a small nonunion manufacturing firm they find that the introduction of a performance appraisal system that is more acceptable to the employees than the former system increases trust towards top management. Blunsdon/Reed (2003) base their analysis on the Australian Workplace Industrial Relations Survey. Their results indicate that trust towards a company's management is correlated to different industry and workplace features as well as a variety of human resource practices. For

\footnotetext{
${ }^{2}$ For other studies on the determinants of trust and also on the comparison of survey attitudes with behavior in experiments see Glaeser et al. (2000), Gächter/Herrmann/Thöni (2004) or Holm/Danielson (2005).

3 The relation of trust and control between companies is analyzed for instance in conceptual contributions by Das/Teng (1998, 2001) as well as by Inkpen/Currall (2004).
} 
example, they find that trust is higher if the management devotes some time to corporate ethics and lower if policies and procedures are formalized. Also, Gould-Williams (2003) concentrates on the relationship of human resource practices and trust - plus other variables, e.g. employee effort or job satisfaction - in an organization. The study is based on a crosssection dataset of public-sector workers in Wales. It can be confirmed that the bundle of HR practices analyzed here has a positive significant effect on systems and interpersonal trust. This bundle of HR practices includes a variety of practices that are assumed to induce superior performance, e.g. performance-related pay and selective hiring.

Our study closes a gap in the literature by focusing on the relationship of different workplace characteristics and the general trust attitude towards others. The analysis has the advantage that it is based on representative samples of people living in Germany (GSOEP) respectively in 24 Europeen countries (ESS) and not on a single company or industry. ${ }^{4}$ Besides profound information on individuals' biographies, on the company's size, industry as well as individuals' job status both GSOEP and ESS contain information regarding some workplace characteristics. Analyzing the German case, we make use of information on the degree of monitoring of performance at the workplace, working time regulations as well as information on the performance appraisal system. Furthermore, we take a measure for individual autonomy at the workplace from the European dataset into account. As we may measure trust like in most other economic studies by using the general trust question from the General Social Survey which had been included in GSOEP in 2003 as well as in the ESS in 2002, 2004 and in 2006, our work directly contributes to the recent studies on the determinants of general trust.

We follow the hypothesis of the literature outlined above by assuming that an individual's trust attitude towards others may be shaped by previous experiences and environmental factors. For example, Alesina/La Ferrara (2002) find that general trust is negatively associated with being separated/divorced or previous traumatic experiences. Or, Rainer/Siedler (forthcoming) confirm that trust is shaped by the institutional environment, i.e. the political regime. As the workplace plays a major role in many employees' lives we conjecture that workplace characteristics could have an affect on the general trust attitude towards others. In particular, we assume here that a higher degree of control at the workplace is negatively correlated with the general trust level of an individual. The underlying idea regarding this

\footnotetext{
${ }^{4}$ The GSOEP is conducted by the German Institute for Economic Research (DIW). Detailed information of the GSOEP is provided on the web page at http://www.diw.de/english/soep/26636.html. The ESS is jointly organized by several European institutions. Information on sampling and data can be found at http://www.europeansocialsurvey.org/ .
} 
conjecture is that being intensely monitored could teach individuals not to rely on trust (only), but on institutional mechanisms as mistrust is a dominant pattern of behavior. ${ }^{5}$

To approximate the degree of control at the workplace we include questions regarding work hour regulations, the use of a formal performance appraisal system, a question on whether an employee's work is monitored (GSOEP) as well as a question on the individuals' autonomy in organizing the own work (ESS). In particular, we hypothesize that trust should be highest for employees who may autonomously vary their working time while it should be lowest for individuals with the lowest degree of time autonomy, i.e. people who have to stick to certain work hours set by the employer or a supervisor. Our conjecture regarding the possible effect of a performance appraisal system is not as straightforward. The measurement of performance may simply be perceived as control of the employer and as such decrease trust. On the other hand, employees may also perceive performance measurement as a necessity for a fair equitybased evaluation of employees. Thus, it might foster trust because participants can rely on an outcome based on performance; this argument particularly applies to good performers. We, therefore, do not have a clear conjecture for overall interrelation between the use of performance appraisal systems and trust. Moreover, we can make use of a question on the degree of monitoring activities by the supervisor at the workplace. We hypothesize that this degree of monitoring at the workplace is negatively related to trust. With our last hypothesis we conjecture that in the European dataset the degree of organizing the own work autonomously is positively related to trust.

\section{Empirical Analysis for Germany (GSOEP)}

\subsection{Data, Variables and Methodology}

We make use of GSOEP, a representative data set of people living in Germany, for which individuals are asked yearly about various areas of life including general attitudes and their employment relationship. We are mainly interested in the relation of trust and workplace characteristics in employment relationships. Therefore, we restrict our sample to full- and part-time employees (blue collars, white collars, civil servants) with a maximum age of 65 (the regular retirement age). In addition, we do not take individuals into account who only

\footnotetext{
${ }^{5}$ Of course, it is also possible that individuals with certain attitudes, e.g. a low degree of trust, self-select themselves rather to environments where control is prevalent. With our analysis we may not differentiate between these two arguments.
} 
have a so called mini-job, which is compensated with at most $€ 400$ per month. This leads to a sample size of 5,385 individuals.

A measure of trust has only been introduced in the year 2003 to the questionnaire so that we have to stick to a cross section analysis. Individuals are asked: "In general, one can trust people”. Individuals have to answer this question on a four-digit-scale (Totally disagree, disagree slightly, agree slightly, totally agree). More than half of the employees state that they slightly agree to this statement (see Table 1). This measure of general trust is somewhat more detailed than that of the often used General Social Survey, where people are offered a twodigit-scale for their answer. In analogy to most other studies (La Porta et al. 1997, Alesina/La Ferrara 2002, Bellemare/Kröger 2007) we concentrate on this measure of general trust. In spite of having information on peoples' trust only for the year 2003, we make use of the panel character of the data set by also using some information of other years. We take three different aspects of control in the employment relationship into account:

First, we explore the relation between working hour regulations and trust. Individuals state their type of regulation in one of the four categories "fixed daily working hours", "(unsteady) working hours fixed by employer", “own commitment of working hours” and "flextime within a working hours account”. The majority of over 40 percent indicates that they have fixed daily working hours (see Table 1 also for descriptive statistics of the control variables). According to the theoretical consideration of section 2 we hypothesize that trust is highest for employees who have the highest degree of autonomy over their own working time, which is the category "own commitment of working hours".

Second, we examine whether the use of a formal performance appraisal system is correlated with trust. Theoretical arguments are somewhat ambiguous as discussed in section 2 . Information on performance appraisals are only given in the 2004 wave of the GSOEP. That is why we have to limit this part of our study to employees, who did not change their job from 2003 to 2004 for this part of our analysis. This further restriction reduces the sample size of about 10 percent to 4,788. The performance is assessed by a supervisor of about one third of employees.

Third, we analyze the degree of monitoring. Employees have to state whether their work is "not at all”, "partly” or "completely” strictly monitored. Most likely this is the most obvious measure of control in the employment relationship. This is why we expect a negative relationship of monitoring and trust. The information on the degree of workplace monitoring is queried only in 2001. Therefore, we have to further restrict our sample to individuals who 
have not changed jobs in 2001 or later, which reduces the number of observations of another 13 percent to 4,177 .

Table 1: Descriptive statistics of trust and control variables

\begin{tabular}{|c|c|c|}
\hline & $\mathbf{n}$ & $\begin{array}{l}\text { Relative } \\
\text { frequency }\end{array}$ \\
\hline Trust people & $(5,385)$ & \\
\hline Totally disagree & 202 & 0.083 \\
\hline Disagree slightly & 1,766 & 0.328 \\
\hline Agree slightly & 3,133 & 0.582 \\
\hline Totally agree & 284 & 0.053 \\
\hline Work hour regulations & $(5,385)$ & \\
\hline Fixed daily working hours & 2,434 & 0.452 \\
\hline (Unsteady) working hours fixed by employer & 1,179 & 0.219 \\
\hline Own commitment of working hours & 550 & 0.102 \\
\hline Flextime within a working hours account & 1,222 & 0.227 \\
\hline$\underline{\text { Performance appraisal }}$ & $(4,788)$ & \\
\hline Yes & 1,551 & 0.324 \\
\hline No & 3,237 & 0.676 \\
\hline Work strictly monitored & $(4,118)$ & \\
\hline Completely & 580 & 0.141 \\
\hline Partly & 1,872 & 0.455 \\
\hline Not at all & 1,666 & 0.405 \\
\hline
\end{tabular}

There are also other individual and job based characteristics, which may influence trust in this context as shown by previous studies. We take sex, age, marital and health status, schooling degree and the existence of siblings into account. We also control for the region, because there might be differences between West and East Germany due to the very different economic and social system in East Germany before the re-unification in 1990 and the following transformation process. Furthermore, we control for relevant job based characteristics like tenure, working hours, type of contract, wage, job status, firm size and industry in our analysis. Descriptive statistics of these variables are shown in Table 2. 
Table 2: Descriptive statistics of other variables

\begin{tabular}{|c|c|c|}
\hline & $\begin{array}{l}\text { Mean } \\
\text { (Share) }\end{array}$ & $\begin{array}{l}\text { Standard } \\
\text { deviation }\end{array}$ \\
\hline Sex (Male=1) & 0.558 & \\
\hline Region (West $=1$ ) & 0.734 & \\
\hline Age (years) & 42.28 & 10.02 \\
\hline Years of Schooling (years) & 12.48 & 2.62 \\
\hline Fulltime (dummy) & 0.816 & \\
\hline Temporary contract (dummy) & 0.057 & \\
\hline Tenure (years) & 0.116 & 9.916 \\
\hline Actual working hours (per week) & 39.82 & 9.279 \\
\hline $\begin{array}{l}\text { Difference between desired and actual } \\
\text { working hours squared }\end{array}$ & 66.94 & 167.52 \\
\hline Wage $(€)$ & $2,520.85$ & 1327.97 \\
\hline Siblings (dummy) & 0.873 & \\
\hline Marital status & & \\
\hline Married & 0.671 & \\
\hline Separated/divorced/widowed & 0,116 & \\
\hline Single & 0.213 & \\
\hline$\underline{\text { Health status }}$ & & \\
\hline Very good & 0.096 & \\
\hline Good & 0.491 & \\
\hline Satisfactory & 0.316 & \\
\hline Poor & 0.088 & \\
\hline Bad & 0.011 & \\
\hline Industry: & & \\
\hline Farming, forestry, fishery & 0.013 & \\
\hline Manufacturing & 0.293 & \\
\hline Construction & 0.063 & \\
\hline Trade and transportation & 0.186 & \\
\hline Financial and company services & 0.112 & \\
\hline $\begin{array}{c}\text { Public and private services } \\
\text { Firm size: }\end{array}$ & 0.336 & \\
\hline 1-4 employees & 0.058 & \\
\hline 5-19 employees & 0.147 & \\
\hline 20-99 employees & 0.202 & \\
\hline 100-199 employees & 0.103 & \\
\hline 200-1999 employees & 0.241 & \\
\hline 2000+ employees & 0.250 & \\
\hline Job status: & & \\
\hline Untrained blue collar worker & 0.020 & \\
\hline Semi-trained blue collar worker & 0.110 & \\
\hline Trained blue collar worker & 0.156 & \\
\hline Foreman & 0.028 & \\
\hline Master craftsman & 0.018 & \\
\hline Untrained white collar worker & & \\
\hline Trained white collar worker & $\begin{array}{l}0.031 \\
0.079\end{array}$ & \\
\hline Qualified professional & 0.298 & \\
\hline $\begin{array}{l}\text { Highly qualified professional } \\
\text { Managerial position }\end{array}$ & 0.163 & \\
\hline Low/middle level civil servant & 0.018 & \\
\hline High level civil servant & 0.028 & \\
\hline Executive civil servant & 0.038 & \\
\hline
\end{tabular}




\subsection{Results}

The general trust variable serves as the dependent variable in our analysis. We start with some bivariate considerations in this section. Accounting for a bunch of different characteristics as described above - we apply a multivariate regression approach. Since our trust variable is measured on a four-digit ordinal scale, we make use of an ordered probit estimation. The measures of control are integrated as sets of dummy variables each and we also include the other individual and job based characteristics.

Exploring the relation between trust and control at the workplace we start with some simple crosstabs. Table 3 indicates the distribution of each specific attribute for control (work hour regulations, existence of a performance appraisal system, degree of being monitored by the supervisor) over the four degrees of trust. It is shown that the fraction of individuals with fixed daily working hours who totally mistrust others is more than twice as high compared to employees with a working hours account or an own commitment of hours. In general, a $\chi^{2}$ test reveals that trust and working hour regulations are not statistically independent. In contrast, there are no considerable differences in trust between individuals whose performance are and are not assessed based on this bivariate base. Employees who are strictly monitored completely state more than twice the time that they totally distrust than others. Again, a $\chi^{2}$ test reveals no independence.

However, the individual trust level might also be affected due to other characteristics. Therefore, we run some ordered probit estimations described by Table 4 . In each of the regressions we include 5 dummies regarding the individuals' health status, 6 dummies regarding the industry the employee is working in, 6 dummies based on the firm size as well as 13 dummies derived from the job status. The results of the variables representing control in the employment relationship can be found in the bottom part of the table. We only make use of the information gathered in 2003 in model (1) so that the existence of a performance appraisal and the degree of monitoring are not yet taken into account here. The results with respect to working hour regulations show that individuals who may commit themselves to working hours trust more than others who have no autonomy over their working hours. The effect is only weakly significant, though. 
Table 3: Crosstabs of trust and control variables (relative frequencies)

\begin{tabular}{|c|c|c|c|c|c|}
\hline & \multicolumn{4}{|c|}{ Trust people } & \multirow[b]{2}{*}{$\chi^{2}$ test } \\
\hline & $\begin{array}{c}\text { Totally } \\
\text { disagree }\end{array}$ & $\begin{array}{c}\text { Disagree } \\
\text { slightly }\end{array}$ & $\begin{array}{c}\text { Agree } \\
\text { slightly }\end{array}$ & $\begin{array}{c}\text { Totally } \\
\text { agree }\end{array}$ & \\
\hline \multicolumn{6}{|l|}{ Work hour regulations } \\
\hline Fixed daily working hours & 0.052 & 0.328 & 0.565 & 0.055 & \multirow{4}{*}{$\begin{array}{r}\mathrm{p}=0.000 \\
(* * *)\end{array}$} \\
\hline (Unsteady) working hours fixed by employer & 0.036 & 0.367 & 0.554 & 0.043 & \\
\hline Own commitment of working hours & 0.024 & 0.267 & 0.620 & 0.089 & \\
\hline Flextime within a working hours account & 0.017 & 0.317 & 0.624 & 0.042 & \\
\hline \multicolumn{6}{|l|}{$\underline{\text { Performance appraisal }}$} \\
\hline Yes & 0.032 & 0.032 & 0.592 & 0,056 & \multirow[t]{2}{*}{$\mathrm{p}=0.574$} \\
\hline No & 0.036 & 0.033 & 0.584 & 0.052 & \\
\hline \multicolumn{6}{|l|}{ Work strictly monitored } \\
\hline Completely & 0.074 & 0.398 & 0,472 & 0,055 & \multirow{3}{*}{$\begin{array}{c}\mathrm{p}=0.000 \\
(* * *)\end{array}$} \\
\hline Partly & 0.031 & 0.325 & 0,598 & 0,046 & \\
\hline Not at all & 0.028 & 0.289 & 0,631 & 0,062 & \\
\hline Total & 0.036 & 0.317 & 0.594 & 0.054 & \\
\hline
\end{tabular}

Note: $* * *$ indicate statistical significance at the $1 \%$ level.

The wage in the current year does not have an effect on trust. It may well be the case, however, that not the absolute wage level but the wage increase from the previous year affects individuals' trust. The wage increase might be perceived as a success which leads to an increased level of trust as suggested by Alesina/La Ferrara (2002). That is why we insert the wage of the year 2002 in model (2). Doing this, we directly analyze the effect of a relative wage increase. The regression approach can be written as:

$$
\text { Trust }_{t}=\alpha \cdot \ln W A G E_{t}+\beta \cdot \ln W A G E_{t-1}+\gamma^{\prime} X+\varepsilon,
$$

where $X$ describes the vector of the other independent variables. As can easily be seen after a simple transformation, the effect of wage increases are measured directly with this approach as (1) is equivalent to

$$
\text { Trust }_{\mathrm{t}}=(\alpha+\beta) \cdot \ln W A G E_{t}-\beta \cdot\left[\ln \left(W A G E_{t} / W A G E_{t-1}\right)\right]+\gamma^{\prime} X+\varepsilon .
$$

If a realized wage increase fosters trust, we may expect a negative value for the estimated coefficient $\beta$ in this specification. The coefficient has the right sign, but is far from statistically significant $(\beta=-0.051, \mathrm{p}=0.524)$. Thus, the result hints that trust cannot clearly 
be generated by wages or wage increases. We, therefore, skip the wage of the year 2002 from the further analysis in order to keep as many observations as possible.

We have already discussed the effect of a performance appraisal system on people's trust. The results of model (3) show that there is indeed no significant effect. Unfortunately, we have no information on the actual outcome of the performance appraisal of each individual. We suppose that good marks may foster trust and weak ones may reduce it. Furthermore, the effect of the appraisal system could depend on its acceptance among employees. For example, the fact whether the performance appraisal system is well communicated to employees such that the system and its outcomes are well understood could be decisive here. Employees who do not understand the system will probably accept their rating more reluctantly, perceive being evaluated as a bad experience and consequently trust less.

We include the monitoring information in model (4). We can confirm the hypothesis that employees who are completely monitored trust significantly less. Thus, we can confirm that there is a clear indication to a negative relation between trust and control.

Table 4 also shows interesting results regarding the other independent variables. These additional results can be compared to the literature on the determinants of trust as most of the variables had also been included in previous studies. In our dataset, we find no effect of gender on trust which is in line with Bellemare/Kröger (2007). Their result is based on behavior in an experiment integrated into a survey of a representative sample of the Dutch population. However, Alesina/La Ferrara (2002) show that groups that are historically discriminated, e.g. women, exhibit less trust because of negative reciprocity (see also Rainer/Siedler forthcoming for a negative effect of being female).

Being located in West instead of the former East Germany has a positive effect on trust. This is in line with the results of Rainer/Siedler (forthcoming) who show that East Germans trust less - shortly after the reunification as well as more than a decade later - than West Germans. They conjecture that this difference is due to negative economic experiences of East Germans (see also Fuchs-Schündeln/Alesina 2007 who analyze differences among preferences between West and East Germans).

We find a positive correlation between trust and age which is not confirmed by most other studies. Rainer/Siedler (forthcoming) find a positive correlation of age and trust only for East Germans who have been living under the communist regime for more years than younger participants. Gächter/Herrmann/Thöni (2004) show a positive correlation of two other GSS 
questions - regarding the expectation of other individuals' helpfulness and fairness - and age but not the general trust question. Fehr et al. (2002) state that participants above 65 trust less based on behavior in the experiment integrated into the survey. Thus, their result is based on a different measure. Moreover, we only include employees up to an age of 65 in our sample.

As depicted by Table 4, in models (1) to (4) trust obviously increases in our dataset with education which seems a robust result in the literature (e.g. Alesina/La Ferrara 2002, La Porta et al. 1997 or Bellemare/Kröger 2007 as well as Fehr et al. 2002 regarding behavior in the investment game). This relation could be explained by another approach to why trust differs among individuals. In our study, we have so far focused on the question whether the general trust attitude of individuals is shaped by the environment in particular by characteristics of the workplace. It is also often claimed that trust is a moral attitude that is highly correlated with individual characteristics, e.g. education. In this sense, trusting others is perceived as a behavioral pattern that can be learnt.

Interestingly, the number of actual working hours has a negative effect on trust. This could be due to people who are working a lot and are doing this reluctantly, i.e. people who are somehow forced to work more than they want. We, therefore, also include the squared difference between desired working hours per week and actual working hours. A descriptive analysis of this variable shows that the large majority of participants would indeed like to work less than they actually do. However, the difference has no effect on trust. Thus, obviously spending time at work has a negative effect on trust, maybe because the workplace as such is in general a less "familiar" or "friendly" or "trustful" environment than the individuals' home or some other place where people voluntarily want to spend time after work, e.g. at a friend's home.

We find a strong and highly significant negative effect of being divorced, separated from the partner or widowed on the general trust attitude. This negative effect of being divorced/separated on trust is also stressed by Alesina/La Ferrara (2002). They claim that trust is related to recent traumatic experiences and in this sense a divorce/separation or a partner's death may be interpreted as a traumatic experience. 
Table 4: Determinants of individual trust (ordered probit estimates)

\begin{tabular}{|c|c|c|c|c|c|}
\hline & (1) & (2) & (3) & (4) & (5) \\
\hline Sex $[$ Male=1] & $\begin{array}{l}-0.003 \\
(0.042)\end{array}$ & $\begin{array}{l}-0.004 \\
(0.044)\end{array}$ & $\begin{array}{c}0.009 \\
(0.045)\end{array}$ & $\begin{array}{c}0.015 \\
(0.049)\end{array}$ & $\begin{array}{c}0.001 \\
(0.067)\end{array}$ \\
\hline Region [West=1] & $\begin{array}{c}0.237 * * * \\
(0.039)\end{array}$ & $\begin{array}{c}0.240 * * * \\
(0.042)\end{array}$ & $\begin{array}{c}0.264^{* * *} \\
(0.042)\end{array}$ & $\begin{array}{c}0.232 * * * \\
(0.046)\end{array}$ & $\begin{array}{l}0.111^{*} \\
(0.061)\end{array}$ \\
\hline Age & $\begin{array}{c}0.007 * * * \\
(0.002)\end{array}$ & $\begin{array}{c}0.008 * * * \\
(0.002)\end{array}$ & $\begin{array}{c}0.008 * * * \\
(0.002)\end{array}$ & $\begin{array}{c}0.007 * * * \\
(0.003)\end{array}$ & $\begin{array}{l}0.006^{*} \\
(0.004)\end{array}$ \\
\hline Years of Schooling & $\begin{array}{c}0.032 * * * \\
(0,009)\end{array}$ & $\begin{array}{c}0.033^{* * * *} \\
(0.009)\end{array}$ & $\begin{array}{c}0.033^{* * * *} \\
(0.009)\end{array}$ & $\begin{array}{c}0.027 * * * \\
(0.010)\end{array}$ & $\begin{array}{c}0.006 \\
(0.013)\end{array}$ \\
\hline Fulltime [dummy, 1=yes] & $\begin{array}{l}-0.006 \\
(0.062)\end{array}$ & $\begin{array}{c}0.020 \\
(0.067)\end{array}$ & $\begin{array}{c}-0.013 \\
(0.068)\end{array}$ & $\begin{array}{c}-0.017 \\
(0.074)\end{array}$ & $\begin{array}{l}-0.001 \\
(0.097)\end{array}$ \\
\hline Temporary contract [dummy, 1=yes] & $\begin{array}{c}0.024 \\
(0.070)\end{array}$ & $\begin{array}{c}-0.051 \\
(0.079)\end{array}$ & $\begin{array}{c}0.075 \\
(0.082)\end{array}$ & $\begin{array}{c}-0.072 \\
(0.113)\end{array}$ & $\begin{array}{c}-0.295^{* *} \\
(0.148)\end{array}$ \\
\hline Tenure [years] & $\begin{array}{c}0.003 \\
(0.002)\end{array}$ & $\begin{array}{c}0.003 \\
(0.002)\end{array}$ & $\begin{array}{c}0.002 \\
(0.002)\end{array}$ & $\begin{array}{c}0.001 \\
(0.002)\end{array}$ & $\begin{array}{l}-0.000 \\
(0.003)\end{array}$ \\
\hline Actual working hours [per week] & $\begin{array}{c}-0.009 * * * \\
(0.003)\end{array}$ & $\begin{array}{c}-0.009 * * * \\
(0.003)\end{array}$ & $\begin{array}{c}-0.009 * * * \\
(0.003)\end{array}$ & $\begin{array}{c}-0.009 * * * \\
(0.003)\end{array}$ & $\begin{array}{c}-0.011^{* *} \\
(0.005)\end{array}$ \\
\hline $\begin{array}{l}\text { Difference between desired and actual } \\
\text { working hours squared [per week] }\end{array}$ & $\begin{array}{l}-0.000 \\
(0.000)\end{array}$ & $\begin{array}{l}-0.000 \\
(0.000)\end{array}$ & $\begin{array}{l}-0.000 \\
(0.000)\end{array}$ & $\begin{array}{l}-0.000 \\
(0.000)\end{array}$ & $\begin{array}{l}-0.000 \\
(0.000)\end{array}$ \\
\hline $\begin{array}{l}\text { Siblings [dummy, } 1=\text { yes] } \\
\qquad \text { Marital status (base: } \text { married) }\end{array}$ & $\begin{array}{c}0.061 \\
(0.048)\end{array}$ & $\begin{array}{c}0.066 \\
(0.050)\end{array}$ & $\begin{array}{c}0.056 \\
(0.051)\end{array}$ & $\begin{array}{c}0.078 \\
(0.055)\end{array}$ & $\begin{array}{c}0.009 \\
(0.076)\end{array}$ \\
\hline $\begin{array}{l}\text { Separated/divorced/widowed } \\
\text { Single }\end{array}$ & $\begin{array}{c}-0.161 * * * \\
(0.049) \\
-0.039 \\
(0.046)\end{array}$ & $\begin{array}{c}-0.160 * * * \\
(0.052) \\
-0.038 \\
(0.048)\end{array}$ & $\begin{array}{c}-0.171 * * * \\
(0.053) \\
-0.027 \\
(0.049)\end{array}$ & $\begin{array}{c}-0.161 * * * \\
(0.057) \\
-0.041 \\
(0.054)\end{array}$ & $\begin{array}{l}-0.105 \\
(0.094) \\
-0.063 \\
(0.081)\end{array}$ \\
\hline Ln(Gross wage) [year 2003] & $\begin{array}{c}0.076 \\
(0.057)\end{array}$ & $\begin{array}{c}0.118 \\
(0.088)\end{array}$ & $\begin{array}{c}0.059 \\
(0.062)\end{array}$ & $\begin{array}{l}0.068 \\
(0.068)\end{array}$ & $\begin{array}{c}0.025 \\
(0.094)\end{array}$ \\
\hline Ln(Gross wage) [year 2002] & --- & $\begin{array}{l}-0.051 \\
(0.080)\end{array}$ & --- & --- & --- \\
\hline Trust of other household members & --- & --- & --- & --- & $\begin{array}{r}0.564^{* * *} \\
(0.051)\end{array}$ \\
\hline$\frac{\text { Work hour regulations (base }=\text { Unsteady }}{\text { working hours fixed by employer) }}$ & & & & & \\
\hline Fixed daily working hours & $\begin{array}{c}0.013 \\
(0.042)\end{array}$ & $\begin{array}{c}0.019 \\
(0.044)\end{array}$ & $\begin{array}{l}0.007 \\
(0.069)\end{array}$ & $\begin{array}{c}0.015 \\
(0.049)\end{array}$ & $\begin{array}{c}0.082 \\
(0.067)\end{array}$ \\
\hline Own commitment of working hours & $\begin{array}{l}0.113^{*} \\
(0.064)\end{array}$ & $\begin{array}{c}0.101 \\
(0.069)\end{array}$ & $\begin{array}{c}0.078 \\
(0.069)\end{array}$ & $\begin{array}{c}0.040 \\
(0.075)\end{array}$ & $\begin{array}{c}0.032 \\
(0.105)\end{array}$ \\
\hline Flextime within a working hours account & $\begin{array}{l}-0.002 \\
(0.070)\end{array}$ & $\begin{array}{l}-0.007 \\
(0.051)\end{array}$ & $\begin{array}{l}-0.015 \\
(0.052)\end{array}$ & $\begin{array}{l}-0.035 \\
(0.055)\end{array}$ & $\begin{array}{l}-0.003 \\
(0.074)\end{array}$ \\
\hline $\begin{array}{l}\text { Performance appraisal [dummy, } 1=\text { yes }] \\
\text { Work strictly monitored (base }=\text { not at all) }\end{array}$ & --- & --- & $\begin{array}{l}-0.001 \\
(0.040)\end{array}$ & $\begin{array}{l}-0.009 \\
(0.043)\end{array}$ & $\begin{array}{c}0.027 \\
(0.058)\end{array}$ \\
\hline Partly & --- & --- & --- & $\begin{array}{c}-0.038 \\
(0.040)\end{array}$ & $\begin{array}{l}-0.044 \\
(0.054)\end{array}$ \\
\hline Completely & --- & --- & --- & $\begin{array}{c}-0.189 * * * \\
(0.063)\end{array}$ & $\begin{array}{c}-0.211^{* *} \\
(0.083)\end{array}$ \\
\hline Health and job status, Industry, Firm size & Yes & Yes & Yes & Yes & Yes \\
\hline \# Observations & 5,385 & 4,942 & 4,788 & 4,118 & 2,383 \\
\hline Pseudo-R² & 0.044 & 0.044 & 0.046 & 0.047 & 0.078 \\
\hline
\end{tabular}

Notes: Robust standard errors in parantheses. * significant at $10 \%$, ** significant at $5 \%, * * *$ significant at $1 \%$. 
Some studies describe different types of trust among which dispositional trust usually plays a major role (for a review of the conceptualization of trust in organizational theory see Kramer 1999). It is assumed that people vary considerably in their predisposition to trust others which is perceived as some personal characteristic shaped by early trust-related experiences. ${ }^{6}$ This hypothesis is in line with Dohmen et al. (2006) who show that there is an intergenerational correlation in risk and trust attitudes, i.e. the trust attitude seems to be transferred from parents to their children. Controlling for a disposition to trust others could shed additional light on our results. If the significant effects of control at the workplace on trust is robust when controlling for dispositional trust we might conclude that the trust attitude is partly shaped by environmental factors like the characteristics at the workplace. The argument that people with a certain disposition to trust others rather self-select themselves to certain types of occupations could be weakened. In our dataset, we may approach the measurement of dispositional trust by matching individual data of members of the same household. ${ }^{7}$ We assume that often people living in the same household, e.g. family members, have similar attitudes such that the average trust of the other household members might serve as a good proxy for dispositional trust. This argument is included in model (5). Here, we have inserted the arithmetic mean of trust of other household members, which reduces the sample size considerably. As expected there is a strong relation of individuals' and other household members' trust. Interestingly, the strong significant negative effect of control at the workplace remains if we include our proxy for dispositional trust.

However, there are also some differences between model (4) and (5). Most importantly the coefficients for schooling and the marital status are not significant any more in model (5) although they were highly significant in model (4). We can only speculate that the fact that a participant is living with someone else in the same household is an indicator for having overcome the negative experience of a separation/divorce or death of partner. ${ }^{8}$ Regarding the effect of schooling one might be tempted to assume that rather highly educated people are living in the same household with others. However, the comparison of the average years of schooling across the two groups, i.e. participants with or without other household members in the survey, yields no difference.

\footnotetext{
${ }^{6}$ Our hypotheses from above are rather based on the concept of "history-based trust" according to which trust is shaped by the history of interacting with others in certain environments (see also Kramer 1999).

${ }^{7}$ We could also measure the parents' trust directly and use it as a dispositional measure. However, our dataset is then reduced to only a very small fraction of our original sample.

${ }^{8}$ Of course, there could also be participants in the sample who are living with others in the same household, but who are the only ones of this household participating in the survey. However, we can be sure that those participants from households with several members participating in the survey are not living alone. Thus, on average we should expect the fraction of single households in the group of participants who have been taken out of the sample in model (5) to be higher than on average in a representative sample.
} 
Finally note that running a regression over the 2,430 individuals included in regression (5) without the independent variable regarding the trust level of other household members virtually yields the same significant coefficients as depicted by (5). Thus, the effects as shown by (5) are not somehow due to the inclusion of the average trust level of other household members.

\section{Analysis for Europe (ESS)}

\subsection{Data, Variables and Methodology}

We can make use of a second dataset of employees. In sum, individuals of 24 European countries are asked in three sequential surveys in 2002, 2004, 2006. Each wave constitutes an independent representative sample so that individuals are not followed over time. We try to make the analysis based on this European dataset as comparable as possible to our analysis of GSOEP. Therefore, we restrict our sample to employees with the same characteristics as above (e.g. only full-time employees are considered). This results in a sample size of 44,373 individuals for all three waves taken together.

The ESS questionnaire also contains the general trust question. In all three waves individuals are asked: "Generally speaking, would you say that most people can be trusted, or that you can't be too careful in dealing with people?” Employees may answer on an 11-digit scale from 0 (you can't be too careful)to 10 (most people can be trusted). Concerning the degree of autonomy at the workplace participants are asked: "Please say how much the management at your work allows you to decide how your own daily work is organized?”. Again, answers are surveyed on an 11-digit scale from 0 (I have no influence) to 10 (I have complete control). Descriptive statistics are shown in Table 5.

Table 5: Descriptive statistics of trust and control variables $(n=44,373)$

\begin{tabular}{|lcccc|}
\hline & Mean & $\begin{array}{c}\text { Standard } \\
\text { deviation }\end{array}$ & Min & max \\
\hline Trust people & 5.416 & 2.341 & 0 & 10 \\
Autonomy at workplace & 6.167 & 3.294 & 0 & 10 \\
\hline
\end{tabular}


According to our argumentation in the previous section our conjecture is that a high degree of autonomy at the workplace is positively related to individuals' trust. Similar to our analysis of GSOEP we take several other individual and job based characteristics into account that may also be associated to trust. An overview of these variables and their descriptive statistics can be found in Table A of the appendix. Note that individuals from Estonia, Hungary and the Ukraine are not included in our analysis due to lack of data on household income.

\subsection{Results}

First, the partial correlation coefficient $(r=0.18, p<0.001)$ hints that there is a positive relation between autonomy at the workplace and individuals' general trust. This correlation differs only slightly across years (2002: $r=0.18,2004: r=0.19,2006: r=0.17)$. We also provide a multivariate analysis, which is comparable to the GSOEP examination. Interestingly, it turns out that the significant relation remains also if we control for a bunch of individual and job based characteristics (Table 6). ${ }^{9}$

Taking a look at the other variables that possibly determine trust we find that similar variables are significantly related to trust in the European dataset as in GSOEP. Trust is positively related to age and years of schooling; and it is negatively correlated with actual working hours per week. Moreover, participants who are divorced, separated or widowed trust significantly less than those being married. Temporary contracts are negatively related to the individual's trust attitude compared to working under a contract of unlimited duration.

\footnotetext{
9 The results are robust with respect to an examination of all 24 countries. Including Estonia, Hungary and the Ukraine (and neglecting household income due to lack of data in these countries) the coefficient for autonomy of work organization is also highly significant and even much larger. A separate analysis for single years shows a decreasing significance over time.
} 
Table 6: Determinants of individual trust (ordered probit estimates) in Europe

\begin{tabular}{|c|c|}
\hline & Pooled data (2002, 2004 and 2006) \\
\hline Sex $[$ Male=1] & $\begin{array}{c}0.042^{* *} \\
(0.018)\end{array}$ \\
\hline Age & $\begin{array}{c}0.005^{* * *} \\
(0.001)\end{array}$ \\
\hline Years of Schooling & $\begin{array}{c}0.025^{* * *} \\
(0.002)\end{array}$ \\
\hline $\begin{array}{l}\text { Past unemployment spell }>3 \text { months } \\
\text { [dummy, 1=yes] } \\
\text { Contract (base: } \text { unlimited) }\end{array}$ & $\begin{array}{l}-0.051^{* * *} \\
(0.018)\end{array}$ \\
\hline Temporary contract & $\begin{array}{c}0.023 \\
(0.021)\end{array}$ \\
\hline No contract & $\begin{array}{l}0.068^{*} \\
(0.038)\end{array}$ \\
\hline Actual working hours [per week] & $\begin{array}{c}-0.003^{* * *} \\
(0.001)\end{array}$ \\
\hline Number of people in household & $\begin{array}{l}-0.005 \\
(0.007)\end{array}$ \\
\hline Citizen of country [dummy, 1=yes] & $\begin{array}{c}0.001 \\
(0.042)\end{array}$ \\
\hline \multicolumn{2}{|l|}{ Marital status (base: married) } \\
\hline Separated/divorced/widowed & $\begin{array}{c}-0.057 * * \\
(0.025)\end{array}$ \\
\hline Single & $\begin{array}{c}0.035 \\
(0.022)\end{array}$ \\
\hline \multicolumn{2}{|l|}{ Household income (base: up to $6000 €$ ): } \\
\hline $6000-12000 €$ & $\begin{array}{c}0.087 * * * \\
(0.034)\end{array}$ \\
\hline $12000-18000 €$ & $\begin{array}{c}0.110^{* * *} \\
(0.037)\end{array}$ \\
\hline $18000-24000 €$ & $\begin{array}{c}0.153^{* * *} \\
(0.038)\end{array}$ \\
\hline $24000-30000 €$ & $\begin{array}{c}0.182 * * * \\
(0.040)\end{array}$ \\
\hline $30000-36000 €$ & $\begin{array}{c}0.209 * * * \\
(0.040)\end{array}$ \\
\hline $36000-60000 €$ & $\begin{array}{c}0.203^{* * *} \\
(0.040)\end{array}$ \\
\hline More than $60000 €$ & $\begin{array}{c}0.193 * * * \\
(0.044)\end{array}$ \\
\hline Autonomy of work organization & $\begin{array}{c}0.008^{* * *} \\
(0.002)\end{array}$ \\
\hline $\begin{array}{l}\text { Health status (5), industry (6), firm size (5), type } \\
\text { of job (10), country (21), and year (3) dummies }\end{array}$ & Yes \\
\hline \# Observations & 44,373 \\
\hline Pseudo-R ${ }^{2}$ & 0.040 \\
\hline
\end{tabular}

Notes: Robust standard errors in parentheses. * significant at $10 \%,{ }^{* *}$ significant at $5 \%,{ }^{* * *}$ significant at $1 \%$. Design and population size weights are taken into account. 
The experience of being unemployed for over three months sometimes in the past is obviously negatively related to trust. The possible explanation is in line with the rationale for our finding that divorced, separated or widowed individuals tend to trust less than married ones: Traumatic or bad experiences seem to reduce individuals' trust towards others. Finally, we find that male participants rather exhibit trust compared to female respondents which is in line with the results of. Alesina/La Ferrara (2002). They explain their finding with the argument that groups of people being historically discriminated against tend to trust less which also applies to women. Note that others, e.g. Bellemare/Kröger (2007) do not find any gender effects.

Regarding our other control variables we find that participants with a subjectively better health status tend to trust more than those rating their health less favorably. And, respondents with a higher household income trust more than those with lower household incomes (see also Alesina/La Ferrara 2002).

In Table 6 we also include dummy variables for each country. Of course, trust and autonomy at the workplace may differ considerably across countries. Our figure below depicts the average trust levels as well as the average degrees of autonomy at the workplace per country over the three waves. It is obvious that a high (low) level of autonomy is associated with a high (low) degree of trust in an inter-country analysis (see Table B in the appendix for exact values). The correlation of both is quite impressive $(r=0.83)$ and varies only slightly across single years between $r=0.79$ and $r=0.85$. There are only minor differences for each country over time.

Checking for possible clusters of countries we find that Scandinavian countries are located in the upper right part of the figure, i.e. showing a high average level of trust as well as a rather high degree of autonomy at the workplace. In the lower left East European countries are depicted with low trust and autonomy levels. This interesting finding hints at important differences at the country-level regarding trust and autonomy at the workplace ${ }^{10}$. As we focus on individual determinants of trust in this paper, country comparisons must be investigated in a future study.

\footnotetext{
${ }^{10}$ For an analysis of empowerment at the workplace and social capital on the basis of the first wave of ESS please see Meulemann (2002).
} 
Figure: Averages of trust and autonomy by country (2002, 2004 and 2006 pooled)

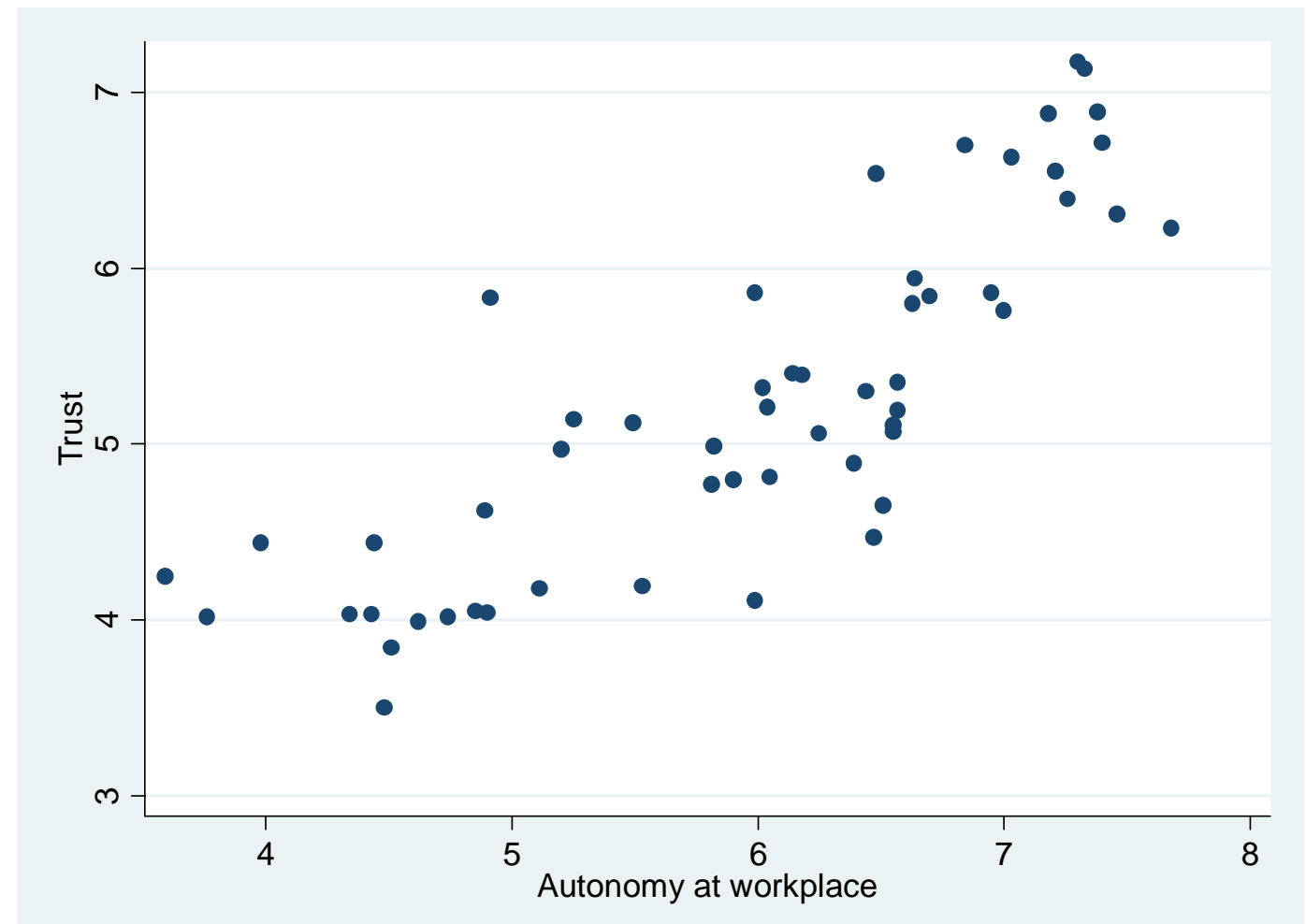

\section{Conclusion}

Based on representative data of employees in Germany and the majority of European countries, we analyze the relation of trust and the use of control mechanisms in employment relationships. We find some evidence for an inverse relation between control mechanisms and individuals' general stated level of trust. In particular, employees who are strictly monitored by a supervisor and have little autonomy to organize their own work seem to trust less. There are also differences for people working under different working time regimes. As already indicated we are unable - as it is typically the case for studies on trust proxied by a questionnaire - to unambiguously identify the causal direction of our effect. Our hypothesis as well as the logic of our argumentation is in line with other studies, but we do not have panel data and can, thus, not exclude the possibility that individuals who are rather trusty tend to sort themselves to workplaces with a lower degree of control exhibited by the supervisor. And, one could argue that low levels of trust may make it necessary to implement strict 
control mechanisms in firms. However, we could at least confirm that our effect prevails even if we include an approximate measure for the disposition to trust which gives us some hope that control indeed affects trust. Will the trust questions be re-introduced in GSOEP, also changes in trust and control mechanisms can be examined in the future.

The results are important for the question of performance management in firms. One usual approach to increase individual effort in firms is the use of some kind of performance related pay. Obviously, some control mechanisms are necessary to have a basis for making appropriate decisions on bonuses or promotions and dismissals. Of course, we do neither deny possible positive incentive effects of performance pay nor the necessity to exert control at the workplace. However, our results might suggest that control mechanisms may have to be introduced cautiously if the intra-organizational trust level is to be kept constant. An alternative implication would be that the design and implementation of certain control mechanisms in an organization may help to attract, retain and motivate certain types of employees, e.g. those with a pronounced tendency to trust others. More generally, one might conclude that - based on our findings - control at the workplace seems to be well aligned to the employees' level of trust in an organization.

Interestingly, it is found in several studies that intra-organizational trust can be monetarily beneficial for firms by both saving control costs and enhancing employees' productivity. For example, Deckop et al. (1999) show in a case study that monetary incentives might be unnecessary, if the corporate culture is stamped by trust between management and subordinates. Falk/Kosfeld (2006) find experimental evidence that trust pays off in terms of higher exerted efforts in a stylized experiment with monetary payoffs.

Finally, we find some interesting and considerable differences between European countries regarding average trust levels and the degrees of autonomy at the workplace. There is a strong correlation of both measures across countries, and countries can obviously be systematically clustered to groups of certain trust and autonomy levels. To find the determinants at the country level for this pattern seems an interesting issue for future research. 


\section{References}

Alesina, A. and E. La Ferrara (2002): Who trusts others? Journal of Public Economics 85, 207-234.

Ashraf, N., I. Bohnet and N. Piankov (2006): Decomposing Trust and Trustworthiness. Experimental Economics 9 (3), 193-208.

Bellemare, C. and S. Kröger (2007:) On Representative Social Capital. European Economic Review, 51, 183-202.

Berg, J., J. Dickhaut and K. McCabe (1995): Trust, Reciprocity, and Social History. Games and Economic Behavior 10, 122-42.

Blunsdon, B., Reed, K. (2003): The effects of technical and social conditions on workplace trust. International Journal of Human Resource Management 14 (1), 12-27.

Das, T.K. and B.-S. Teng (1998): Between Trust and Control: Developing Confidence in Partner Cooperation in Alliances. Academy of Management Review 23, 491-512.

Das, T.K. and B.-S. Teng (2001): Trust, Control, and Risk in Strategic Alliances: An Integrated Framework. Organization Studies 22/2, 251-283.

Deckop, J. R.; R. Mangel; C. C. Cirka (1999): Getting More than You Pay for: Organizational Citizenship Behavior and Pay for Performance Plans. Academy of Management Journal (42), 420-428.

Dickinson, D. and M.-C. Villeval (2004): Does Monitoring Decrease Work Effort? The Complementarity between Agency and Crowding-Out Theories. IZA Discussion Paper No. 1222.

Dohmen, T., Falk, A., Huffmann, D., Sunde, U., Schupp, J. and G. G. Wagner (2005): Individual Risk Attitudes: New Evidence from a Large, Representative ExperimentallyValidated Survey. IZA Discussion Paper No. 1730.

Dohmen, T., Falk, A., Huffmann, D., Sunde, U. (2006): The Intergenerational Transmission of Risk and Trust Attitudes. IZA DP No 2380.

Falk, A. and M. Kosfeld (2006): Distrust - The Hidden Cost of Control. American Economic Review 96 (5), 1611-1630

Fehr, E., Fischbacher, U., von Rosenbladt, B. and J. Schupp (2002): A Nation-Wide Laboratory. Examining Trust and Trustworthiness by Integrating Behavioral Experiments into Representative Surveys. Schmollers Jahrbuch 122 (4), 519-542.

Fuchs-Schündeln, N. and A. Alesina (2007): Good Bye Lenin (Or Not?): The Effect of Communism on People's Preferences. American Economic Review, 97(4), 1507-1528.

Fukuyama, F. (1995): Trust. New York: Free Press.

Gächter, S., Herrmann, B. and C. Thöni (2004): Trust, Voluntary Cooperation, and SocioEconomic Background: Survey and Experimental Evidence. Journal of Economic Behavior and Organization 55, 505-531.

Glaeser, E. L., Laibson, D., Scheinkman, J. and C. Soutter (2000): Measuring Trust. Quarterly Journal of Economics 115, 811-846.

Gould-Williams, J. (2003): The importance of HR practices and workplace turst in achievieng superior performance: a study of public-sector organizations. International Journal of Human Resource Management 14 (1), 28-54.

Harbring, C. (2007): The Effect of Incentive Schemes on Trust and Trustworthiness. Working Paper, University of Cologne.

Holm, H. J. and A. Danielson (2005): Tropic Trust versus Nordic Trust: Experimental Evidence from Tanzania and Sweden. The Economic Journal 115, 505-532. 
Inkpen, A. C. and S. C. Currall (2004): The Coevolution of Trust, Control, and Learning in Joint Ventures. Organization Science 15, 586-599.

Knack, S. and P. Keefer (1997): Does Social Capital Have an Economic Payoff? A CrossCountry Investigation. Quarterly Journal of Economics 112, 1251-1288.

Kramer, R. M. (1999): Trust and Distrust in Organizations: Emerging Perspectives, Enduring Questions, Annual Rev. Psych. 50, 569-598.

La Porta, R., Lopez-de-Silanes, F., Shleifer, A. and. R. Vishny (1997): Trust in Large Organizations, American Economic Review Papers and Proceedings 87, 333-338.

Mayer, R. C. and Davis, J. H. (1999): The Effect of the Performance Appraisal System on Trust for Management: A Field Quasi-Experiment. Journal of Applied Psychology 84 (1), 123-136.

Meulemann, H. (2002): Social Capital in Europe: Similarity of Countries and Diversity of People? Multi-level analyses of the European Social Survey. Leiden: Brill, 1-37.

Rainer, H. and T. Siedler (forthcoming): Does Democracy Foster Trust? Journal of Comparative Economics

Sapienza, P., Toldra, A. and L. Zingales (2007): Understanding Trust. Working Paper. 


\section{Appendix:}

Table A: Descriptive statistics of other variables $(n=44,373)$

\begin{tabular}{|c|c|c|}
\hline & Mean (Share) & Standard deviation \\
\hline Sex $($ Male=1) & 0.487 & \\
\hline Age (years) & 41.96 & 12.15 \\
\hline Years of Schooling (years) & 13.07 & 3.731 \\
\hline \multicolumn{3}{|l|}{ Contract } \\
\hline Unlimited contract & 0.793 & \\
\hline Temporary contract & 0.153 & \\
\hline No contract & 0.054 & \\
\hline Actual working hours (per week) & 38.85 & 12.62 \\
\hline Past unemployment spell > 3 months (dummy) & 0.306 & \\
\hline Citizen of country (dummy) & 0.955 & \\
\hline \multirow{2}{*}{\multicolumn{3}{|c|}{ Marital status }} \\
\hline & & \\
\hline Married/Civil partnership & 0.579 & \\
\hline Separated/divorced/widowed & 0.137 & \\
\hline Single & 0.285 & \\
\hline \multicolumn{3}{|l|}{ Health status } \\
\hline Very good & 0.271 & \\
\hline Good & 0.485 & \\
\hline Fair & 0.201 & \\
\hline Bad & 0.037 & \\
\hline Very bad & 0.006 & \\
\hline \multicolumn{3}{|l|}{ Household income: } \\
\hline Up to $6000 €$ & 0.082 & \\
\hline $6000-12000 €$ & 0.104 & \\
\hline $12000-18000 €$ & 0.116 & \\
\hline $18000-24000 €$ & 0.121 & \\
\hline $24000-30000 €$ & 0.115 & \\
\hline $30000-36000 €$ & 0.120 & \\
\hline $36000-60000 €$ & 0.212 & \\
\hline more than $60000 €$ & 0.130 & \\
\hline \multicolumn{3}{|l|}{ (1) } \\
\hline Armed Forces & 0.004 & \\
\hline Legislators, Senior Officials, Managers & 0.072 & \\
\hline Professionals & 0.158 & \\
\hline Technicians, Associate Professionals & 0.190 & \\
\hline Clerks & 0.124 & \\
\hline Service, Shops and Market Sales Workers & 0.151 & \\
\hline Skilled Agricultural and Fishery Workers & 0.010 & \\
\hline Craft and Related Trades Workers & 0.120 & \\
\hline Plant and Machine Operators, Assemblers & 0.082 & \\
\hline \multicolumn{2}{|l|}{ Industry: } & \\
\hline Farming, forestry, fishery & 0.018 & \\
\hline Manufacturing & 0.207 & \\
\hline Construction & 0.064 & \\
\hline Trade and transportation & 0.196 & \\
\hline Financial and company services & 0.144 & \\
\hline Public and private services & 0.371 & \\
\hline
\end{tabular}


Table A (continued): Descriptive statistics of other variables $(n=44,373)$

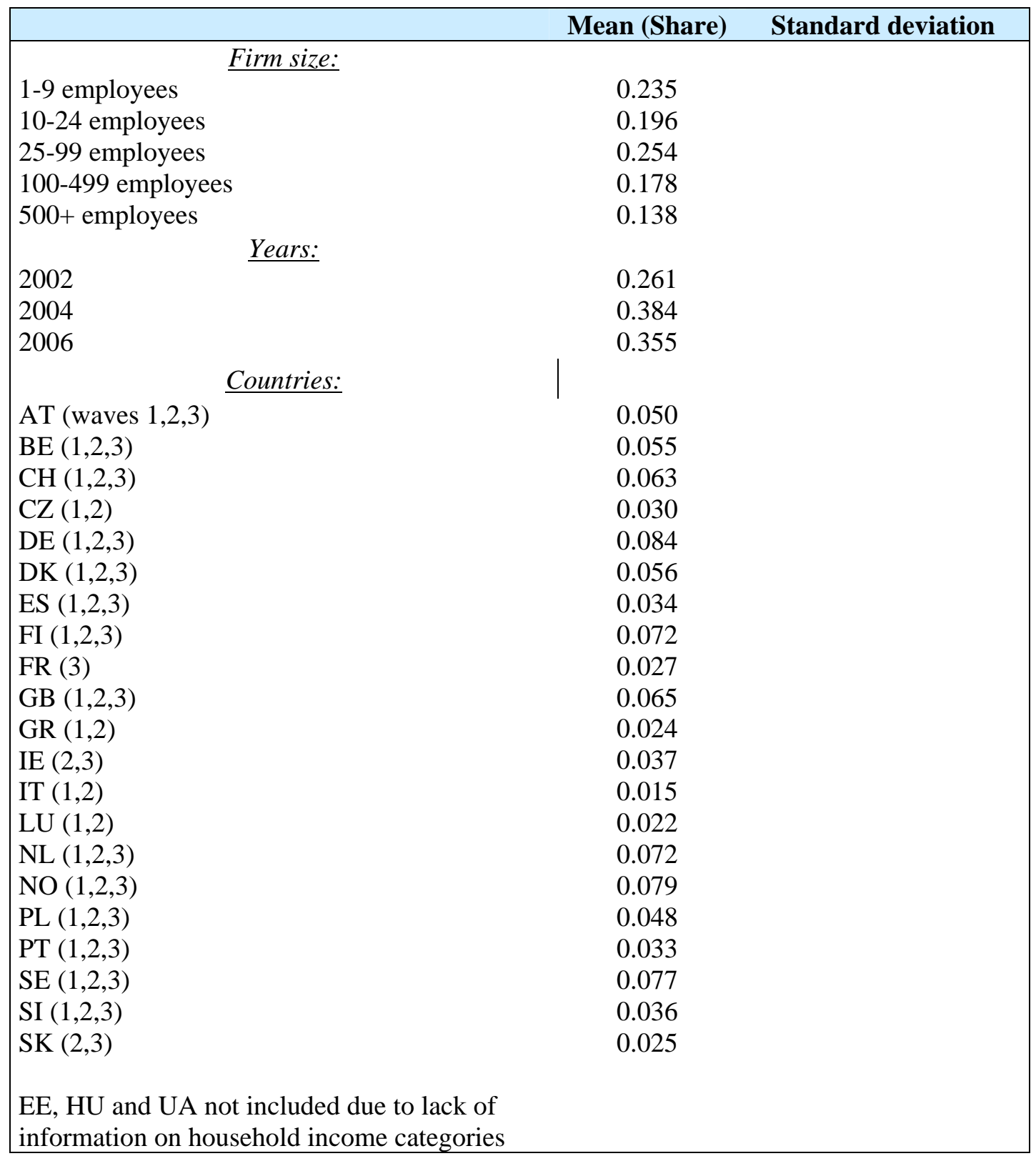


Table B: Averages of trust and autonomy by country and year

\begin{tabular}{|lcccccc|}
\hline & \multicolumn{2}{c}{$\mathbf{2 0 0 2}$} & \multicolumn{2}{c}{$\mathbf{2 0 0 4}$} & \multicolumn{2}{c|}{ 2006 } \\
& Trust & Autonomy & Trust & Autonomy & Trust & Autonomy \\
\hline AT & 5,39 & 6,18 & 5,30 & 6,44 & 4,99 & 5,82 \\
BE & 5,19 & 6,57 & 4,89 & 6,39 & 5,06 & 6,25 \\
CH & 5,94 & 6,64 & 5,76 & 7,00 & 5,80 & 6,63 \\
CZ & 4,44 & 4,44 & 4,25 & 3,59 & --- & --- \\
DE & 4,80 & 5,90 & 4,81 & 6,05 & 4,77 & 5,81 \\
DK & 7,17 & 7,30 & 6,89 & 7,38 & 7,13 & 7,33 \\
EE & --- & --- & --- & --- & --- & --- \\
ES & 5,14 & 5,25 & 5,12 & 5,49 & 5,32 & 6,02 \\
FI & 6,54 & 6,48 & 6,55 & 7,21 & 6,63 & 7,03 \\
FR & --- & --- & --- & --- & 4,47 & 6,47 \\
GB & 5,07 & 6,55 & 5,11 & 6,55 & 5,35 & 6,57 \\
GR & 3,99 & 4,62 & 4,02 & 3,76 & --- & --- \\
HU & --- & --- & --- & --- & --- & --- \\
IE & & & 5,83 & 4,91 & 5,40 & 6,14 \\
IT & 4,65 & 6,51 & 4,62 & 4,89 & --- & -- \\
LU & 5,21 & 6,04 & 4,97 & 5,20 & --- & --- \\
NL & 5,86 & 6,95 & 5,84 & 6,70 & 5,86 & 5,99 \\
NO & 6,70 & 6,84 & 6,71 & 7,40 & 6,88 & 7,18 \\
PL & 3,84 & 4,51 & 3,50 & 4,48 & 4,03 & 4,34 \\
PT & 4,02 & 4,74 & 4,03 & 4,43 & 4,19 & 5,53 \\
SE & 6,31 & 7,46 & 6,23 & 7,68 & 6,39 & 7,26 \\
SI & 4,05 & 4,85 & 4,18 & 5,11 & 4,11 & 5,99 \\
SK & --- & --- & 4,04 & 4,90 & 4,44 & 3,98 \\
UA & --- & --- & --- & --- & --- & --- \\
\hline
\end{tabular}

